\title{
Inside the "Black Box" of River Restoration: Using Catchment History to Identify Disturbance and Response Mechanisms to Set Targets for Process-Based Restoration
}

\author{
Sarah Mika $^{1}$, Joanna Hoyle ${ }^{2}$, Garreth Kyle ${ }^{3}$, Timothy Howell ${ }^{4}$, Benjamin Wolfenden $^{1}$, Darren Ryder ${ }^{1}$, \\ Daniel Keating ${ }^{2}$, Andrew Boulton ${ }^{1}$, Gary Brierley ${ }^{5}$, Andrew P. Brooks ${ }^{4}$, Kirstie Fryirs ${ }^{2}$, \\ Michelle Leishman $^{3}$, Mark Sanders ${ }^{2}$, Angela Arthington ${ }^{4}$, Robert Creese ${ }^{6}$, Mark Dahm ${ }^{1}$, Craig Miller ${ }^{2}$, \\ Brad Pusey ${ }^{4}$, and Alexandra Spink ${ }^{2}$
}

\begin{abstract}
Many river restoration projects fail. Inadequate project planning underpins many of the reasons given for failure (such as setting overly ambitious goals; selecting inappropriate sites and techniques; losing stakeholder motivation; and neglecting to monitor, assess, and document projects). Another major problem is the lack of an agreed guiding image to direct the activities aimed at restoring the necessary biophysical and ecological processes within the logistic constraints of on-ground works. Despite a rich literature defining the components of restoration project planning, restoration ecology currently lacks an explicit and logical means of moving from the initial project vision through to on-ground strategies. Yet this process is fundamental because it directly links the ecological goals of the project to the on-ground strategies used to achieve them. We present a planning process that explicitly uses an interdisciplinary mechanistic model of disturbance drivers and system responses to build from the initial project vision to the implementation of on-ground works. A worked example on the Upper Hunter River in southeastern Australia shows how understanding catchment history can reveal disturbance and response mechanisms, thus facilitating process-based restoration.
\end{abstract}

Key Words: catchment history; complex ecological systems; conceptual modeling; disturbance and response mechanisms; guiding image; Hunter River, Australia; interdisciplinary research; process-based restoration; river restoration

\section{INTRODUCTION}

Why do so many river restoration projects fail? Much emphasis focuses on the components of ecological restoration: having a "guiding image" (sensu Palmer et al. 2005), setting the correct priorities (Wohl 2005, Hobbs 2007), identifying appropriate trajectories and reference states (Hughes et al. 2005, Kondolf et al. 2006), and using suitable on-ground strategies (Nilsson et al. 2007, Spink et al. 2009). Nevertheless, many restoration projects still fail (Wohl et al. 2005). Contributing to this failure are an incomplete understanding of riverine processes and an inadequate recognition of the multiple and interacting temporal and spatial scales of ecosystem disturbance and response (Bernhardt et al. 2005, Lake et al. 2007).
Landscape-level processes interact to drive fluxes of water, sediment, nutrients, energy, and biota between rivers and their catchments to create a dynamic, hierarchical mosaic of interdependent habitats (Ehrenfeld 2000, Pedroli et al. 2002). Rivers are characterized by the interactions of multiple abiotic and biotic processes (Fisher et al. 2007), hydrological disturbances such as floods or drought (Lake 2000), and poorly understood feedback loops (Lansing 2003). System boundaries change dramatically, sometimes irreversibly, once particular thresholds are exceeded (Burkett et al. 2005). Adding to the inherent complexity of river systems are the impacts of multiple disturbances interacting through space and time. Furthermore, direct and indirect linkages among system components transfer repercussions from disturbances

\footnotetext{
${ }^{1}$ School of Environmental and Rural Science, University of New England, Australia, ${ }^{2}$ Department of Environment and Geography, Macquarie University, ${ }^{3}$ Department of Biological Sciences, Macquarie University, ${ }^{4}$ Australian Rivers Institute, Griffith University, ${ }^{5}$ School of Geography, Geology and

Environmental Science, University of Auckland, ${ }^{6} \mathrm{NSW}$ Department of Industry and Innovation, Port Stephens Fisheries Centre, Australia
} 
throughout the river, often in unpredictable and nonlinear ways depending on antecedent conditions, lag times, and thresholds of response (Burkett et al. 2005, Parsons et al. 2006).

Targets for ecological river restoration are also hard to define. Data to comprehensively characterize predisturbance states and pristine reference rivers do not exist for many river types (Nilsson et al. 2007). It is conceptually difficult to define a restoration target based on a pre-disturbed river that no longer exists, and even more challenging to predict how that undisturbed system would itself have changed over time (Hughes et al. 2005). Further, river restoration is constrained by its context of intensifying human pressure on ecosystem components (Wohl 2005, Dufour and Piégay 2009). Thus, reference conditions are often arbitrarily selected points along a river's evolution, preferably set within the spatial and temporal contexts of the catchment (Brierley and Fryirs 2009). Conversely, restoration goals for many projects are clear (e.g., reduce erosion and compaction, reinstate natural flow regimes, and remove or reduce exotic species). Although the goals themselves are conceptually simple, their prioritization and achievement in the face of natural variability and human pressure are difficult. Furthermore, a realistic guiding image must construct biophysical restoration priorities within a framework of social as well as economic opportunities and constraints (Ryder et al. 2008a).

The social and economic constraints are dynamic and complex. Social disconnection with biophysically deteriorating rivers often occurs through the dominance of noncompatible consumptive uses, cultural change, institutional mistrust, and a lack of physical or legal access (Hillman et al. 2008). Socioeconomic opportunities and constraints usually vary at the subcatchment scale, impeding the development of a catchment-scale vision for river restoration (Hillman and Brierley 2005). For example, social disconnection with the upper reaches of the Hunter River catchment (New South Wales [NSW], Australia) has been substantial, driven by regional economic change and associated land and water use. Traditional agriculture such as dairying has given way to coal mines, viticulture operations, and horse stud farms (Spencer et al. 2004). The loss of riparian land to agriculture and mining prevents public access to many river reaches. The economic power of these new industries is perceived to marginalize other stakeholders. Conversely, these new industries own considerable stretches of riparian lands and have the economic capacity to fund riverine restoration.

Given this rich literature, why does the planning process often fail in river restoration projects? We believe a key reason is that the process of restoration project planning is currently a "black box"; the individual components are well known, but we lack an explicit, transparent, and logical way of moving from the guiding image to on-ground works. Although many projects have well-defined goals, the actual pathways and mechanisms by which these will be achieved are rarely considered (Lake et al. 2007). Nonetheless, determining such pathways is a critical step in a restoration project because it directly links the ecological goals of a project to the on-ground strategies used to achieve them.

The first step in a riverine restoration project often entails stakeholders collaboratively developing a vision of the restored ecosystem (the "guiding image" sensu Palmer et al. 2005); this vision is a description of the dynamic, ecologically healthy river that can exist at a specific site given the river's history. In this definition, ecological health encompasses geomorphic, hydrological, and biological aspects, whereas the guiding image only defines the restoration targets. Achieving lasting structural restoration requires understanding and typically reinstating the biophysical processes that create and sustain these structural attributes (Ryder and Miller 2005). A guiding image should encompass a mechanistic understanding of the river system that specifies how the ecosystem works, how it has been impaired, and how on-ground strategies will move it along a restoration trajectory (Jansson et al. 2005). This mechanistic understanding in turn relies on an interdisciplinary understanding not only of biophysical form-function interactions linking geomorphology, hydrology, and ecology (Fisher et al. 2007) but also of social science and policy research.

Here, we describe a process that explicitly builds from the initial project vision to an interdisciplinary conceptual model of disturbance drivers and ecosystem response. We illustrate this process using a river restoration project from the upper Hunter catchment. The regional setting and settlement history of the Hunter catchment are described to identify the causes, the spatial and temporal extents, and the intensities of human disturbances to the river system. This knowledge feeds into an interdisciplinary conceptual model (sensu Sime 2005, Nelson et al. 
2006) that specifies the biophysical processes responsible for the ecological condition of the contemporary upper Hunter River. We focus on processes that can be realistically targeted in the river restoration program and show how on-ground initiatives can directly manipulate these processes to restore ecological structure and function.

\section{DESIGN CONSIDERATIONS FOR A MECHANISTIC GUIDING IMAGE}

Any group deciding on an action strategy must first construct a shared vision of what they want to accomplish. Constructing this vision entails fusing individual knowledge into a collective conceptual framework (Pennington 2008). Because successful river restoration requires framing biophysical restoration priorities and targets within a socioeconomic context, an interdisciplinary approach can usefully synthesize the relationships between socioeconomic and biophysical patterns and processes to articulate system-level processes such as resilience, resistance, persistence, and spatio-temporal variability (Pickett et al. 1999). In practice, interdisciplinary collaborations are notoriously difficult to manage (Likens et al. 2009). However, the advantage of an interdisciplinary approach to designing a guiding image is that it generates system-specific understanding that is both holistic and mechanistic.

The geomorphic template is a logical starting point for biophysical river restoration (Ward et al. 2001, Brierley et al. 2008) because the availability of physical habitat governs not only key ecological processes such as organic matter and nutrient cycling but also resources such as habitat and food for aquatic biota (Harper and Everard 1998, Poole et al. 2006). This approach necessitates understanding a river's physical character and behavior in its specific landscape setting (Wiens 2002). Knowing the river's history is necessary to identify the causes, the spatial and temporal extents, and the intensities of disturbances; to determine the restoration priorities and set realistic restoration targets; to ensure that the suggested on-ground works actually address the disturbance drivers; and to predict possible future states for the river (Brooks and Brierley 2004, Lake 2005).

This knowledge then must be synthesized into a conceptual framework. Conceptual modeling is a valuable tool in refining and communicating this synthesis, both as a process and as a product. As a process, conceptual modeling requires dialogue among disciplines and stakeholders, thereby helping to clarify jargon, knowledge structures, mismatches of scale, biases, and the implicit knowledge of stakeholders (Benda et al. 2002, Heemskerk et al. 2003). As a product, an integrative conceptual model forms the foundational knowledge for restoration (Frothingham et al. 2002) by encapsulating abiotic and biotic components, integrating structural and functional attributes, emphasizing direct and indirect temporal and spatial linkages within a system, recognizing degradation thresholds, and conceptualizing and assessing the self-organizing or emergent characteristics of complex adaptive systems (Cundill et al. 2005, King and Hobbs 2006). Conceptual models not only combine components of physical and ecological integrity but also illustrate the mechanisms leading to the best achievable restoration outcomes under prevailing environmental and socioeconomic conditions.

We have here adapted the methods of Sime (2005) and Nelson et al. (2006) to develop an interdisciplinary conceptual model that identifies drivers of disturbance to guide the restoration of a complex ecosystem. Drivers are defined as "any natural or human-induced factor that directly or indirectly causes a change in an ecosystem" (Nelson et al. 2006). Some drivers (e.g., flow regulation) affect ecosystem processes directly, whereas others work indirectly by influencing further drivers (e.g., clearing of forests in the catchment can indirectly reduce water quality by altering the supply of finegrained sediment to the river). A driver can manifest as several specific stressors. For example, increased suspended loads reduce instream benthic habitat, smother and inhibit organic matter decomposition, and impair predator-prey dynamics (through increased turbidity). These stressors affect the key ecological attributes (sensu Sime 2005) of the system, such as the health of the riparian vegetation, macroinvertebrate, and fish communities. Improvements in the condition of these communities may represent restoration success.

\section{A WORKED EXAMPLE}

The Upper Hunter River Rehabilitation Initiative (UHRRI) was a combined research and restoration project on the degraded upper Hunter River. The project's vision was to produce both a valued community resource and a model for future restoration efforts; in particular, it would create an 
ecologically sustainable riparian plant community dominated by endemic species and reintroduce instream wood to provide habitat for native aquatic biota (Keating et al. 2008). The project commenced in early 2003 with a strategic plan for developing the restoration and research objectives (Table 1). Although the restoration component focused on a single $10-\mathrm{km}$ reach $\left(32^{\circ} 17^{\prime} \mathrm{S}, 150^{\circ} 50^{\prime} \mathrm{E}\right)$, the research component included a catchment-scale synthesis of explorers' journals, parish maps, aerial photographs, oral histories, and published literature. Our objectives were to gain a catchment-scale understanding of interactions between the physical setting and settlement history of the catchment, identify the key disturbance and response mechanisms, and set the restoration priorities. The driver-stressor-attribute approach was used to develop comprehensive conceptual models for individual disciplines (e.g., geomorphology, vegetation ecology, and fish ecology) for presentation at an intensive workshop where the interdisciplinary UHRRI conceptual model was negotiated and refined. Several iterations of the UHRRI model followed the workshop.

\section{Physical context of the Hunter catchment}

The Hunter River is a warm temperate, sand- and gravel-bed river that drains an area of $22,000 \mathrm{~km}^{2}$ to the eastern coast of NSW (Fig. 1). Annual catchment rainfall ranges from 600 to $1400 \mathrm{~mm}$ (Fig. 1, Raine 2000). Coastal and lower subcatchments receive the highest annual rainfall, generally in January through March, with a smaller peak in the mid-winter month of July (ANRA 2008a). The western regions of the catchment are the driest, receiving their peak rainfall in December and January (ANRA 2008a). Average yearly runoff is 1,800,000 ML (DLWC 2000); however, this volume is not distributed evenly across the catchment. The highly irregular climate of the Hunter Valley has resulted in significant droughts and floods (Erskine and Warner 1988), leading to the construction of extensive flood mitigation and impoundment works throughout the catchment (Fig. 1, ANRA 2008a).

The Hunter catchment has diverse geology and topography. A third of the catchment is classified as mountainous (greater than a $15^{\circ}$ slope), including the subalpine areas in the northern highlands (ANRA 2008b). Approximately half of the catchment is classified as undulating, and less than one-quarter is classified as flat (less than a $3^{\circ}$ slope), including the large alluvial floodplain of the Hunter (ANRA 2008b). The inactive Hunter-Mooki Fault divides the catchment into two geologically distinct zones (Fig. 2). Northeast of the fault, units of the New England Fold Belt form rugged and hilly country with a high proportion of mudstone (Fryirs et al. 2007). Tributaries in the northeast originate from elevations of approximately 1200 to $1500 \mathrm{~m}$ above sea level, have relatively high gradients with fast flow, and supply gravels and cobbles to the Hunter River (Raine 2000, Schneider 2007). In contrast, the western catchment comprises units of Sydney Basin sedimentary rocks (shales, sandstones, conglomerates, and coal [Fryirs et al. 2007]) with deeply dissected tributary valleys of highly erodible sandy soils (Schneider 2007). These western tributaries originate at approximately 800 to $1000 \mathrm{~m}$ above sea level, have lower gradients (Fryirs et al. 2007), and supply sand to the Hunter River (Raine 2000). To the northwest, tributaries draining the Liverpool Ranges and Merriwa Plateau are characterized by basaltic gravel and cobble streambeds along with high concentrations of dissolved salts and minerals (Schneider 2007).

\section{Historical context of the Hunter catchment: 1800 to the mid-1990s}

Before European settlement, the catchment was home to the Kamilaroi and Wanaruah indigenous nations. Europeans first explored the catchment in 1797. By the following year, coal was being mined from the valley and cedar cutting had commenced. Land grants were given in proportion to the number of sheep and cattle that settlers were prepared to stock (Fig. 3). By 1827, over 244,500 ha had been settled along $240 \mathrm{~km}$ of the Hunter River, supporting 25,000 cattle and 80,000 sheep (Dangar 1828). These stocking rates were unsustainable even in the short term, and soon stock were being moved upstream in search of grass (Monteith 1953).

At the time of European settlement, the Hunter catchment was floristically diverse, primarily because of its geography and geology. The catchment penetrates well inland but lacks a western escarpment, and therefore it still includes the eastern and western extents of many plant species (Spencer et al. 2004). In the upper estuary, the river was lined by numerous large (over $45 \mathrm{~m}$ tall) trees of Eucalyptus, Casuarina, and native "cedars" along with dense vine brush and a fern understory 
Table 1. Restoration and research objectives of the Upper Hunter River Rehabilitation Initiative, a combined research and restoration project (from Keating et al. 2008).

\section{Restoration Objectives}

1. To understand through monitoring and experimentation the dynamics of the riverine ecosystem of the Hunter River and its response to rehabilitation.

2. To create through revegetation of a 10-km stretch of the Hunter River a riparian plant community that (i) uses species that occurred or likely occurred on the original riparian and floodplain landforms, (ii) becomes self-sustaining, (iii) provides a habitat for terrestrial and aquatic indigenous species, (iv) provides a source of propagules for the natural colonization of native species downstream, (v) ensures bank stability equivalent to that provided by the existing willows (Salix spp.), (vi) improves water quality, and (vii) contributes to carbon storage.

3. To install large instream wood structures that (i) reduce bank erosion; (ii) contribute to the storage and redistribution of sediment to generate dynamic channel morphology appropriate to the local setting; (iii) contribute to the instream storage, transformation, and bioavailability of nutrients; and (iv) increase habitat diversity for fish and other aquatic biota.

4. To contribute to community education and involvement in riverine rehabilitation.

\section{Research Objectives}

1. To determine the effects of land use and geomorphic change throughout the upper Hunter catchment and the resultant downstream impacts on reach-scale processes.

2. To understand (i) how changes in land use affected fluvial geomorphic patterns and processes and (ii) how riparian revegetation and the reintroduction of instream wood affect contemporary fluvial geomorphology.

3. To understand the patterns and processes governing the establishment of vegetation (including exotic species) in a disturbed riparian setting.

4. To understand how reintroduction of instream wood affects (i) channel bathymetry, (ii) benthic and hyporheic processes and biota, and (iii) fish communities.

5. To understand how floristic changes in the riparian zone and geomorphic effects of instream wood reintroductions affect the instream retention and breakdown of organic matter.

(Albrecht 2000). The floodplain was lightly wooded with a luxuriant grass understory, while dense shrub woodland covered the hillslopes. Explorers recorded abundant and diverse fish, shellfish, birds, and mammals in the lower Hunter River and its estuary (Albrecht 2000). The lower catchment was characterized by an impenetrable temperate rainforest that covered much of the floodplain (Spencer et al. 2004). Starting in the 1820s, however, this vegetation was cleared to allow farming in the floodplains, and less than $1 \%$ of the rainforest remains today (Albrecht 2000). The midto upper Hunter valley was characterized by a narrow but dense riparian zone dominated by river oaks (C. cunninghamiana) and river red gums ( $E$. camaldulensis), whereas the alluvial floodplain supported dense grasslands with scattered river red gums, forest red gums (E. tereticornis), and yellow box (E. melliodora; Peake 2003).

The explorers' accounts give little indication of the morphology of the upper Hunter River at the time of European settlement. However, it seems that the river was characterized by steep banks, well-defined pool-riffle sequences, bedrock steps (cascades), and numerous gravel bars (Raine 2000, Spencer et al. 2004). In 1825, Allan Cunningham described the upper Hunter River near Denman as $50 \mathrm{~m}$ wide and 3 m deep with steep banks (Wood 1972). Further upstream, the river was $45 \mathrm{~m}$ wide and too deep for packhorses to cross; that same reach is now $150 \mathrm{~m}$ wide (Raine 2000). The temporal and spatial changes to channel morphology in response to human disturbances have been documented for the 
Fig. 1. Rainfall, streamlines, impoundments, and flow barriers in the Hunter catchment. The UHRRI is the Upper Hunter River Rehabilitation Initiative. Rainfall data were sourced from the NSW Department of Land and Water Conservation (DLWC 2000). The extents of unregulated, controlled, and regulated flow as well as the locations of flow barriers were sourced from Ryder et al. (2008b). High, medium, and low priority refers to the priority for removal of flow barriers to improve fish communities.

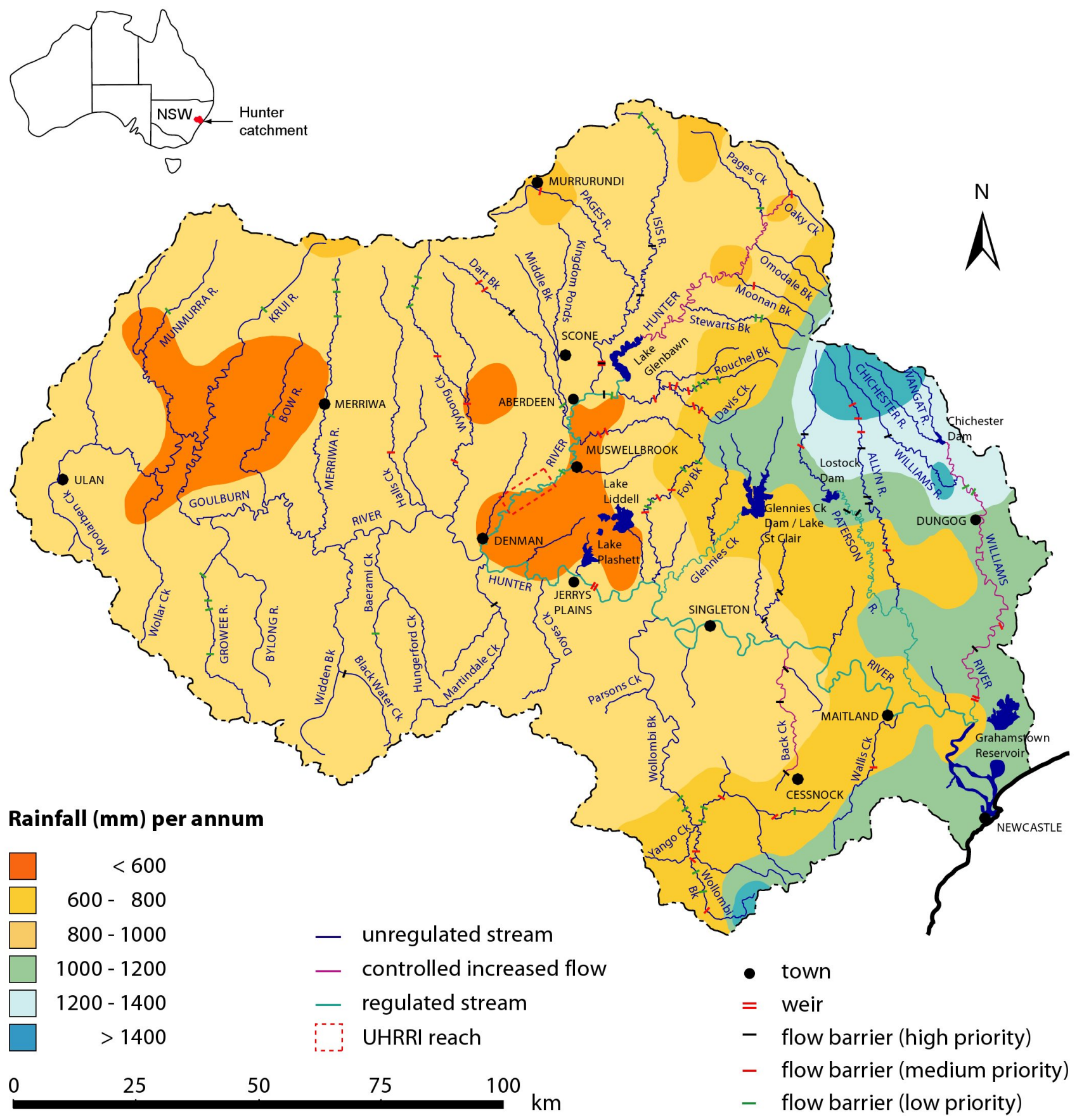


Fig. 2. Geology of the Hunter catchment (modified from DLWC 2000).

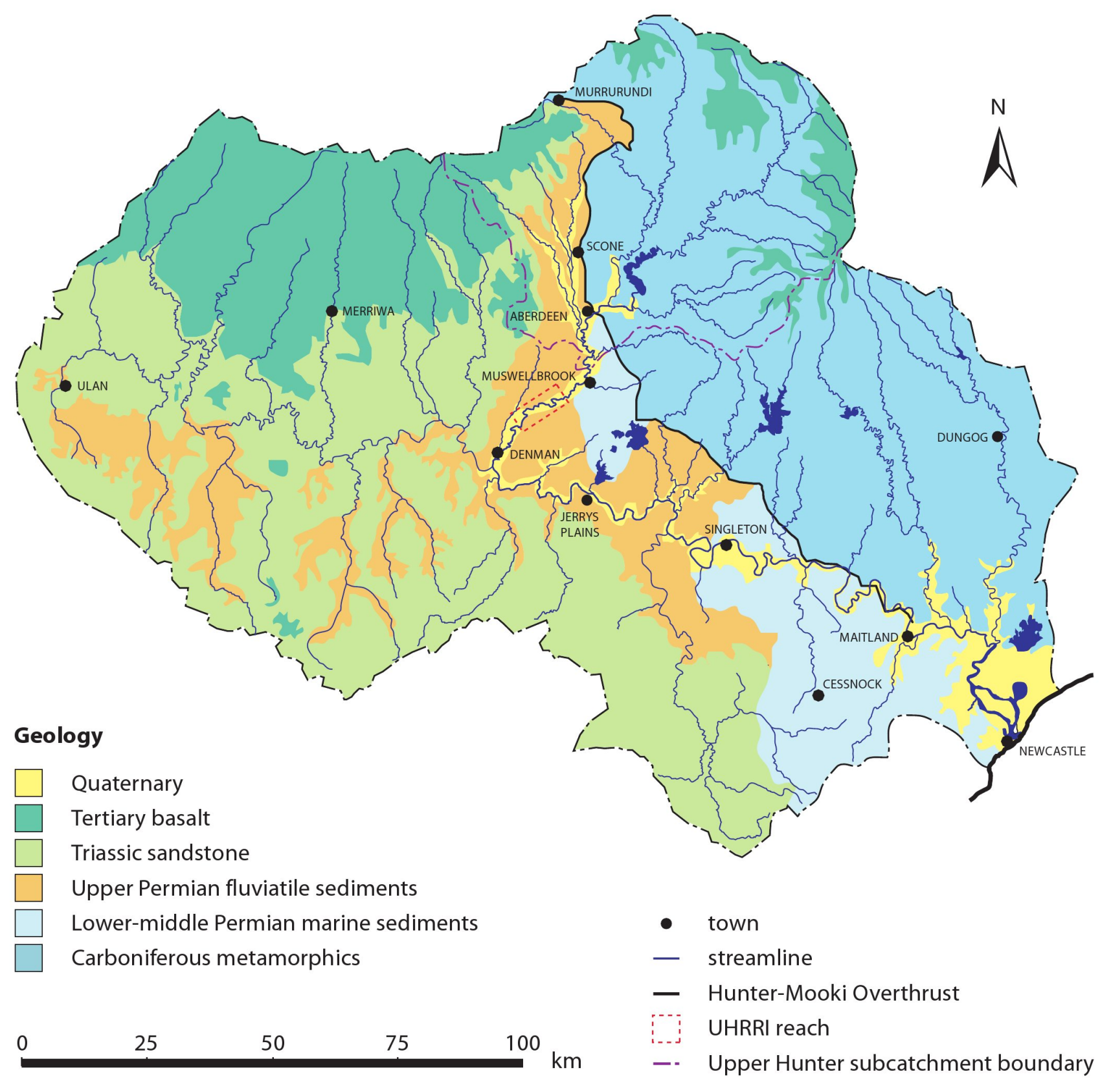


Fig. 3. Timeline of European settlement in the Hunter catchment.

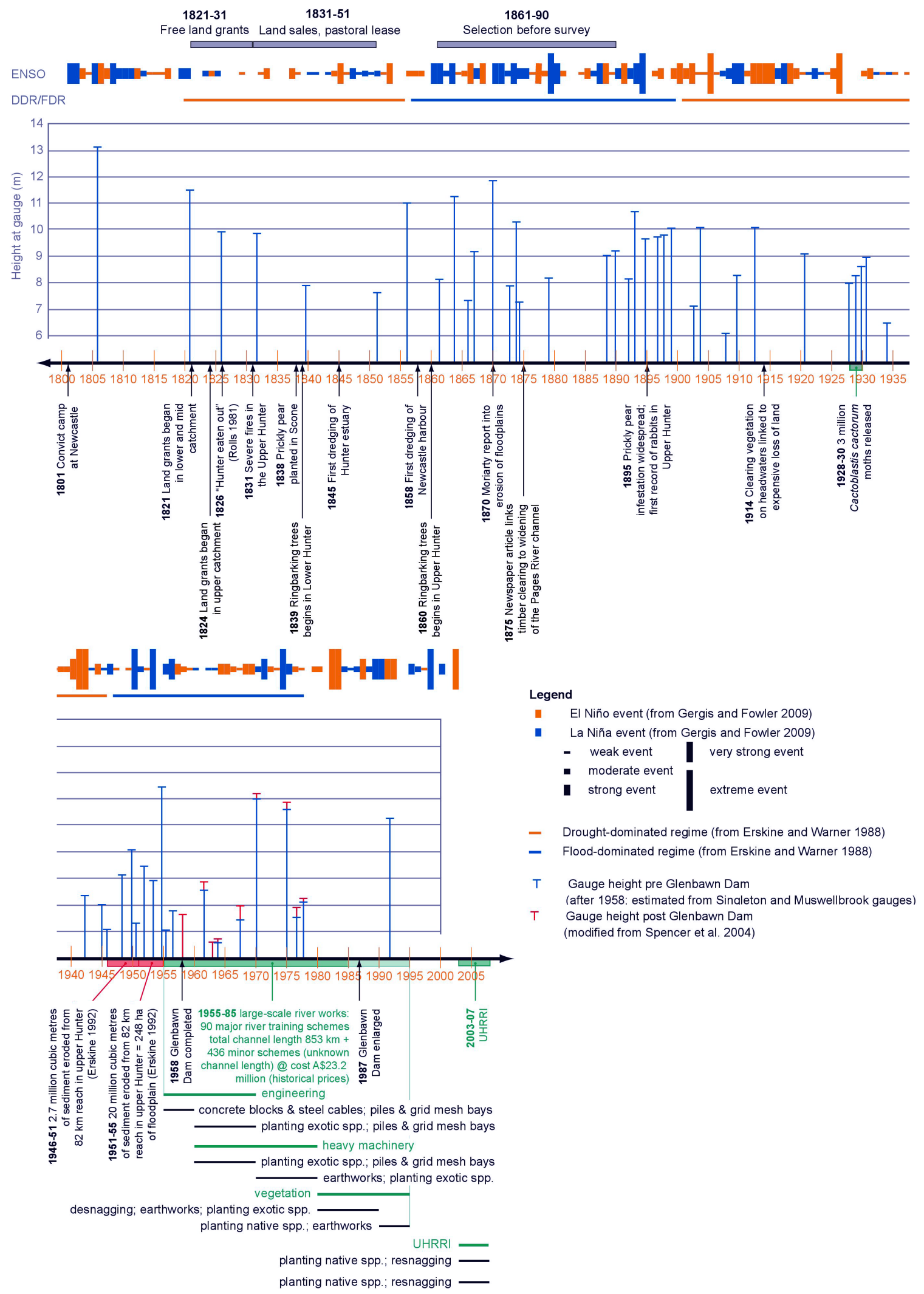


Hunter catchment (Erskine and Bell 1982, Erskine 1985, 1992, Erskine and Webb 2003), the upper Hunter (Fryirs et al. 2007, Fryirs et al. 2009, Spink et al. 2009), and the UHRRI reach (Hoyle et al. 2008). Although the disturbance drivers systematically affected the catchment, the resulting changes in channel morphology lagged 50 to 70 years after initial disturbance and varied considerably at the reach scale (Fryirs et al. 2009). The longitudinal morphologic complexity of the river decreased as a result of desnagging (the removal of riparian and instream trees and wood), accelerated sedimentation, and bed incision (sensu Brooks et al. 2003), whereas its lateral morphologic complexity increased as bar and bench units accreted next to the low-flow channel (Hoyle et al. 2008).

While the geomorphic and floristic responses to European settlement are predictable, it is less clear how these responses affected fundamental riverine processes. Hydrologic exchange between the river and underlying sediments was likely promoted by variability in the longitudinal profile (such as poolriffle sequences) and mediated by high loadings of instream wood (e.g., Brooks and Brierley 2002). The saturated sediments under the river (the "hyporheic zone") probably played an important role in retaining and processing organic matter as well as in nutrient regeneration (e.g., Boulton et al. 1998). In the pre-European river, instream nutrient production was likely controlled by hyporheic exchange, retention by instream wood, and the relatively slow breakdown rates of native plant litter that resulted from its high leaf toughness (Wolfenden et al. 2005, Kyle and Leishman 2009a). Instream wood also likely provided habitat and food for diverse biota ranging from aquatic invertebrates (e.g., Dahm 2006, Scealy et al. 2007) to fish (including Australian bass [Macquaria novemaculeata] and sea mullet [Mugil cephalus]; Brooks et al. 2006, Howell 2008) as well as platypus (Albrecht 2000).

Concern over riparian degradation (particularly bank erosion) culminated in several government reports, including the Moriarty Report (Moriarty 1870), which documented the rapid acceleration of channel expansion and erosion of floodplains in the mid- and lower catchment. In 1875 and 1914, newspaper articles linked channel expansion and erosion of floodplains to the clearing of hillslopes in headwater reaches (Monteith 1953). The degradation did not abate: from 1946 to $1951,2.7 \times$ $10^{6} \mathrm{~m}^{3}$ of sediment were eroded along $82 \mathrm{~km}$ of channel immediately downstream of the current site of Glenbawn Dam (Reddock and Milston 1953 in
Erskine 1992). Between 1951 and 1955, this erosion had increased to $23 \times 10^{6} \mathrm{~m}^{3}$ (or 248 ha of floodplain) along the same reach (Reddock 1957 in Erskine 1992).

The changed channel morphology, the desnagging practices, and the loss of riparian shade likely reduced the habitat available for fish and aquatic invertebrates (e.g., Pusey and Arthington 2003). Desnagging also removed retentive woody material that, under natural conditions, delayed the downstream transport of native leaf litter, allowing for litter conditioning and breakdown by microbes and shredding by invertebrates (Boulton et al. 2004, Wolfenden et al. 2005). The accumulation of finegrained sediments in the gravel bed reduced hydrological exchange between the river and its aquifer, thus impairing hyporheic processes (e.g., Kasahara et al. 2009). The loss of lateral and longitudinal hydrological connectivity (Hoyle et al. 2008), the expansion of the macrochannel (sensu van Niekerk et al. 1999), and the clearing of riparian vegetation probably caused aquatic food webs to increasingly rely on instream (autochthonous) production instead of floodplain and riparian (allochthonous) production, hence causing a net shift from heterotrophy towards autotrophy (Wolfenden et al. 2005).

In response to the widespread floodplain destruction by the 1955 flood (a once-in-100-year event; Fig. 3), Glenbawn Dam was commissioned to provide flood protection as well as water for agriculture, mining, and municipalities. Completed in 1958, this dam captures runoff from one-third of the upper Hunter catchment and traps almost $99 \%$ of the total sediment load (Erskine 1985). Dam operations produce thermally polluted (cold water) discharge that extends far downstream. In addition, extensive riverworks were commissioned from 1955 to 1991 , including engineering works (Spink et al. 2009), riparian revegetation (initially with exotics; e.g., 71,000 willows were planted along $3 \mathrm{~km}$ of riverbank in a single project [Erskine 1992]), and continued removal of instream and riparian trees and wood (Erskine and Webb 2003).

\section{The contemporary upper Hunter River: mid-1990s to 2003}

In the mid-1990s, river management changed significantly in the Hunter (Fig. 3). Desnagging ceased in 1995 (Erskine and Webb 2003), and wood loads in the contemporary channel have increased 
as riparian trees (predominantly willow with some Casuarina) have fallen in. The extensive riverworks triggered the formation and accretion of lateral bars and benches; these surfaces were then often stabilized with exotic vegetation such as willows or poplars as well as Casuarina. These riverworks have contributed to the transition from net erosion (prior to 1960) to net deposition (after 1960; Hoyle et al. 2008), thus promoting geomorphic recovery through channel infilling. Similarly, the riverworks improved habitat conditions for fish by providing structural habitat, hydraulic diversity, and summer shade (Howell 2008).

The increased geomorphic complexity and instream vegetation arising from the riverworks had profound implications for riverine processes. With the reestablishment of instream vegetation, processes at the ecotone between the floodplain and the macrochannel (such as input and conditioning of organic matter, hydrological buffering, and trapping of fine sediments) were relocated to the ecotone between the macrochannel margin and the low-flow channel (Fig. 4). This shift also affected the temporal scale over which these processes occur, because low-lying areas within the macrochannel are inundated more frequently than were the functionally equivalent areas on the floodplain. From a functional perspective, the river contracted within the landscape as within-channel bars and benches inherited the ecological roles previously performed by the floodplain (Mika et al. 2008).

Willows and other exotic riparian species (including grasses and forbs) largely replaced the native treeand-shrub-dominated system that predated European settlement, marking a major shift in plant functional types. In contrast to the original plant communities, contemporary vegetation mainly comprises species with reduced leaf toughness and increased specific leaf area (SLA; Kyle and Leishman 2009a). On bars, the prevailing plant functional type comprises annual species with small seed mass and softer leaves. Benches are dominated by graminoid species with unassisted seed dispersal and tougher leaves, whereas taller perennial species with larger seed mass persist on the banks (Kyle and Leishman $2009 b$ ). This shift in plant functional types markedly changed the ecosystem structure and function. The change from woody species to grasses and forbs reduced shade, increased soil and water temperatures, and increased the light available for instream photosynthesis. The loss of woody species also reduced the net evapotranspiration rate, removed a major nutrient sink (e.g., Clément et al.
2003), and removed a source of wood for the river. The nature and supply of organic matter was completely changed by the replacement of toughleafed evergreen woody perennials with species that produce large autumnal inputs of short-lived and rapidly degraded litter containing low carbon: nitrogen ratios (Wolfenden 2009); thus, the aquatic food web was altered. The removal of instream wood also allowed the softer willow litter to travel rapidly through the system, depriving the food web of the nutrients from even this transient resource. Where the litter did settle, suspended sediment also accumulated, thereby impeding leaf litter breakdown and ultimately reducing aquatic macroinvertebrate diversity (e.g., Wood and Armitage 1997).

Glenbawn Dam reduces flood peaks but sustains low to moderate flows over summer, when discharge was lower historically (Erskine 1985). These reductions in flood peaks and base flow variability have limited the river's capacity for reworking bed sediments and flushing fine-grained sediments, likely severing linkages between the river and its hyporheic zone (Kasahara et al. 2009) as well as starving interstitial invertebrates and aerobic biofilms of oxygen and nutrients from the surface stream. The dam thus reduces the capacity of the hyporheic zone to store and process organic matter, exacerbating the net loss of organic matter from the reach (Fig. 5). Upstream sediment barriers (Fryirs et al. 2007) further limit organic matter inputs, elevating the importance of local riparian vegetation as a source of instream organic matter. Reduction in flood peaks, elevated baseflows, and reduced baseflow variability have also probably masked seasonal environmental cues for spawning of native fish (Pusey et al. 2004), favoring instead exotic fishes such as carp (Cyprinus carpio) and mosquito fish (Gambusia holbrooki) (Bunn and Arthington 2002).

Although anthropogenic changes to flows, channel form, and riparian vegetation have affected aquatic macroinvertebrate assemblages in the lower Hunter River (Chessman et al. 1997), typical functional feeding groups still persist in the UHRRI reach. However, shredding invertebrates capable of comminuting leaf litter are relatively rare, perhaps as a result of the reduction in a reliable, persistent food source. Fine-particle detritivores are abundant, whereas algivores are uncommon (Scealy et al. 2007). Nevertheless, aquatic macroinvertebrate family richness and biological condition are relatively high within the study reach. This diversity 
Fig. 4. The Hunter River at the Singleton rail bridge in (a) 1861, (b) 1866, (c) 1963, and (d) 2003. Note the ringbarked (dead) trees in (a), the actively eroding bank and lack of instream wood in (b), the expansion of the macrochannel in (c), and the reestablishment of a riparian zone (albeit dominated by exotic Salix spp.) as well as the contraction of the low-flow channel in (d). [Photos (a) through (c) are courtesy the NSW Department of Environment, Climate Change and Water historical photo. Photo (d) is by N. Cook, NSW Department of Environment, Climate Change and Water.]

(a)

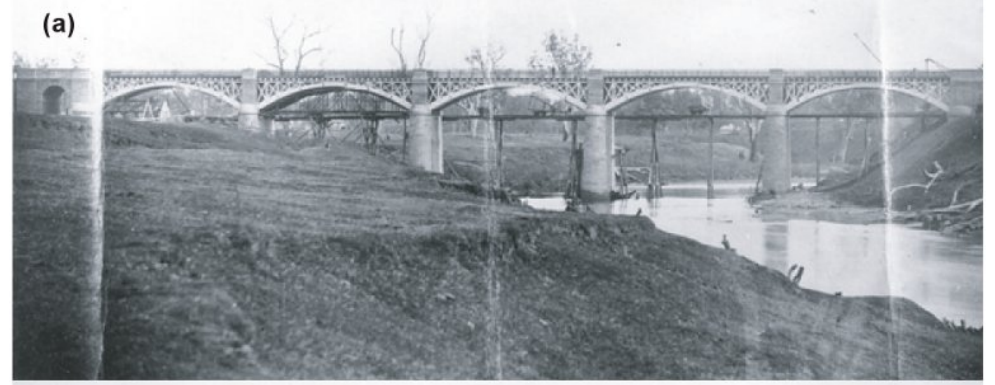

(b)
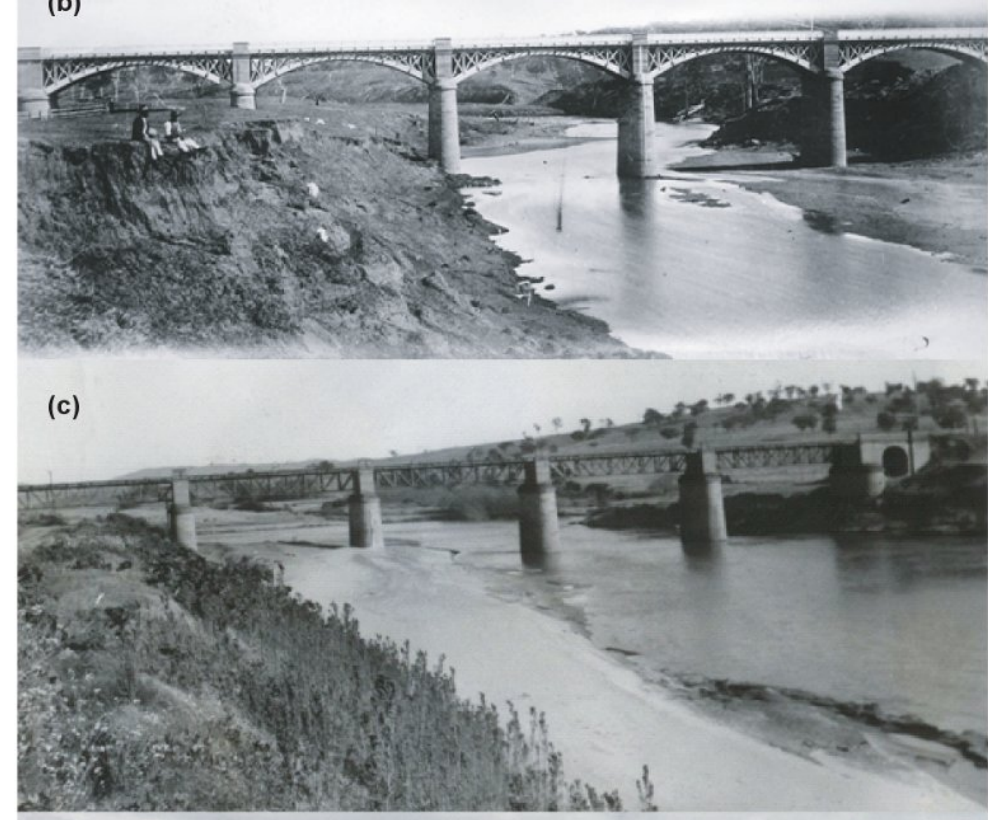

(d)

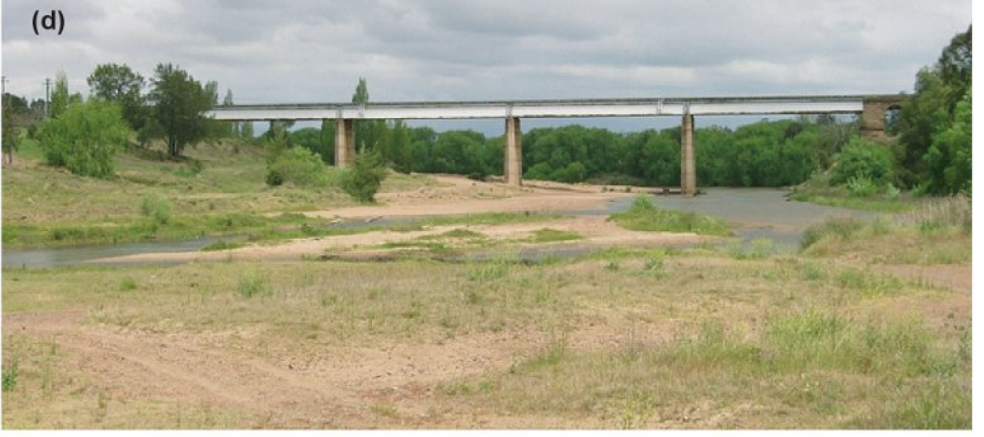


Fig. 5. The interdisciplinary conceptual model of the contemporary starting point (2003) for restoring instream and riparian structure and function in the UHRRI reach. The model emphasizes (i) the key drivers of disturbance in the system that can be tackled by river managers (heavy rectangles), (ii) the specific mechanisms by which these drivers stress the system (ovals), (iii) the direct and indirect interactions of stressors with each other and with system components (light rectangles), and (iv) the ecological attributes affected by these stressors (heavy hexagons).

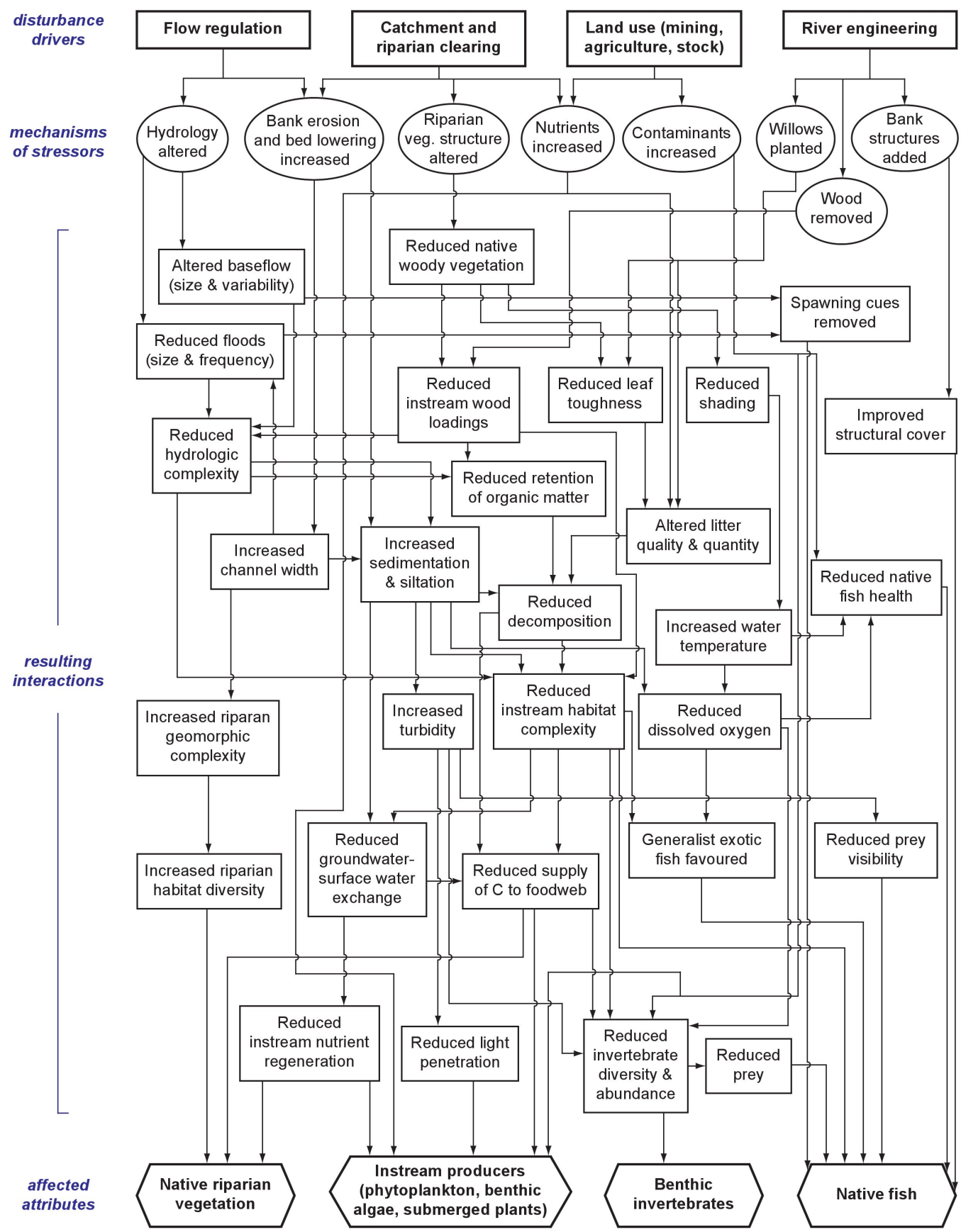


is promoted by hydraulic complexity in riffle and edge habitats and by the beds of water milfoil (Myriophyllum spp.) that proliferate seasonally in riffles (Dahm 2006, Scealy et al. 2007). In pools and silty microhabitats, however, invertebrate diversity is markedly lower: those communities are dominated by chironomid midge larvae and oligochaete worms (Dahm 2006), as seen in other streams rich in fine-grained sediments (Wood and Armitage 1997).

\section{Using the UHRRI conceptual model to frame restoration priorities and strategies}

The conceptual model for the UHRRI was based on the principle that the geomorphic template is the logical starting point for river restoration (Ward et al. 2002, Brierley et al. 2008). By first specifying geomorphic change, the contemporary aquatic and riparian components could be framed in terms of biophysical mechanisms and the net direction of change from pre-European conditions (Fig. 5). Using this model, the success of UHRRI can be measured as the net direction of change in ecosystem attributes and function from the prerestoration condition. Furthermore, because the mechanisms targeted by the restoration strategies are explicitly stated, the effectiveness of these techniques in manipulating these mechanisms can be ascertained. Thus, this approach facilitates the two closely linked assessments that must be made at the conclusion of the restoration effort: the ecological success of the restoration project (system-specific assessment) and the effectiveness of the restoration techniques in promoting the mechanisms (technique-specific assessment).

The Hunter case study demonstrates that a thorough assessment of catchment-scale disturbances and riverine responses is needed to place the contemporary river system in the context of degradation and recovery trajectories (Fig. 5). Restoration strategies must focus on stressors that can be manipulated and target a tractable subset of likely response variables to monitor restoration success. For example, reintroduction of wood into the study reach to restore geomorphic and ecological processes and structure (Fig. 5) was appropriate, given the long history of wood removal from the Hunter River and the effectiveness of engineered log jams as an alternative to the steel and concrete techniques traditionally used for bank stabilization (Spink et al. 2009). Wood structures placed at key locations potentially limit further adjustment of the low flow channel and slow sediment movement through the reach (Brooks et al. 2006). Using the conceptual model (Fig. 5), we can predict that one of the immediate outcomes of the reintroduction of wood will be the provision of structural habitat for fish and aquatic invertebrates. Over time, geomorphic and hydraulic changes induced by localized scour and sedimentation will also create additional microhabitats for aquatic organisms (Dahm 2006).

The importance of the linkages between groundwater and surface water became evident in the development of the conceptual model, especially the increased hydraulic exchange between the hyporheic zone and surface stream wherever logs span part or all of the channel. According to the model, additional nutrients may be delivered to the surface stream via this process (Boulton 2007), supporting the growth of macrophytes and benthic algae. The model also shows that a reduction in large wood reduces the amount of retained litter and other organic matter, limiting food for many macroinvertebrates and fish. The potential for such organic matter to be used by macroinvertebrates also depends on the degree of siltation that occurs in depositional habitats, so the model reveals an important control on the likely mechanism by which wood could enhance leaf retention and breakdown.

The second restoration strategy was the planting of native vegetation along riparian margins to increase native biodiversity. The conceptual model revealed that the changes to the composition of vegetation resulted from the increase in exotic vegetation and the loss of native vegetation. If restoration reverses these stressors, we would expect (1) a structural shift from short, herbaceous vegetation to tall, woody vegetation, and (2) a shift from soft, high SLA leaves to tough leaves with low SLA (Kyle and Leishman 2009a). Changes in the first attribute would increase wood input to the channel over decades, with its associated benefits. Changes in the second attribute would affect foliage quality (increasing carbon: nitrogen and lignin:cellulose ratios) and hence decomposition rates and palatability to invertebrates, both instream (Wolfenden 2009) and in the riparian zone. The reestablishment of tough native leaves with low SLA values will mean that litter persists longer in the system, potentially supporting a greater diversity and abundance of aquatic macroinvertebrates, thus increasing food availability for fish (Fig. 5). However, the model indicates that other constraints (e.g., turbidity and choice of native riparian species) 
could impede the success of these restoration strategies. Consequently, other management activities (e.g., sediment control and environmental flow releases) should also be implemented concurrently.

\section{DISCUSSION}

This conceptual modeling approach has three broad benefits to targeting drivers and stressors and to identifying mechanisms of restoration. (1) Operationally, the approach explicitly guides adaptive management by informing decisions about sensible resource allocation given ecological, social, and economic constraints; by revealing spatial and temporal scales of processes and interactions; by enabling testing of restoration options (tracing potential responses through the biophysical system); and by providing a means for measuring the success of the restoration effort (Palmer et al. 2005). (2) This approach is also a powerful communication tool, providing a rapid, visual overview of the current understanding of the ecosystem. The model gives a context for specific sections of the work (reductionist) yet promotes integration across the entire complex system (holistic), and can be tailored for different audiences to promote knowledge transfer and consensus among stakeholders. (3) Furthermore, the conceptual modeling approach is heuristically valuable in that development and refinement of the model highlights the commonalities and mismatches in the knowledge structures of participating scientists, managers, and stakeholders (Benda et al. 2002); encourages debate on the goals and guiding images of the restoration project (Hobbs 2007); and explicitly illustrates any assumptions underlying the judgments or predictions of outcomes so that such assumptions can be assessed and tested (Boulton et al. 2008).

Explicit definitions of purpose and terms are vital in interdisciplinary efforts that attempt to bridge the divide between restoration science and management. In this instance, the driver-stressor-attribute approach (Sime 2005, Nelson et al. 2006) facilitated integration and linkages among different biophysical components. Several iterations were needed to balance the manipulation of a complex ecological system with the operational and communication goals of the model. Knowledge gaps and mismatches of scale were more evident during the modeling process than could be represented effectively in the finished conceptual model (Fig. 5). The box-and-arrow structure of the diagram misleadingly implies linear relationships of equivalent importance. Furthermore, the apparent complexity of the model implies completeness, but this also is not true: significant knowledge gaps remain in the UHRRI conceptual model. For example, the model is focused only on the biophysical components of restoration and lacks a direct socioeconomic perspective (although some indirect socioeconomic effects emerge from the identification of system drivers). In addition, the levels of uncertainty in our knowledge of feedback loops and causal mechanisms differ for the individual components, particularly with respect to the temporal and spatial extents of processes and interactions. Although these knowledge gaps and uncertainties must be explicitly acknowledged, they do not preclude the usefulness of the model for predicting the probable consequences of the stated restoration strategies of riparian replanting and the reintroduction of instream wood. Instead, the process of developing the conceptual model actually clarified where knowledge gaps, uncertainty, and mismatches of scale occurred in our understanding of this complex ecological system.

Despite the extent of geomorphic degradation and flow regulation as well as the poor condition of riparian vegetation, prospects for restoration along the upper Hunter River are greater than initially envisaged. The conceptual modeling process highlighted the partial geomorphic and riparian recovery of the contemporary river system, with positive implications for ecosystem processes and the biota. Although much improved from 50 years ago, further instream geomorphic complexity is required and can be promoted through the management of riparian vegetation, the installation of wood, and the reinstatement of flow regimes. Short- to medium-term strategies to these ends include promoting greater diversity of hydraulic patches as well as creating and enhancing habitat for macroinvertebrates and fish. Medium- to longterm strategies must target progressive reductions in exotic species of vegetation and fish.

Responses to this article can be read online at:

http://www.ecologyandsociety.org/voll5/iss4/art8/responses/ 


\section{Acknowledgments:}

Most of the data supporting this work were obtained from postgraduate research conducted by Mark Dahm, Tim Howell, Jo Hoyle, Garreth Kyle, Sarah Mika, Alexandra Spink, and Ben Wolfenden, and from postdoctoral research conducted by Kirstie Fryirs. They thank their respective research institutions for logistical and financial support. The authors are grateful for funding from the Australian Research Council and from industry partners Bengalla Mining Company, Mt Arthur Coal, and Macquarie Generation. Riparian revegetation was funded by the Nature Heritage Trust and undertaken by Green Corps, Conservation Volunteers, the NSW Land and Property Management Authority, and contractors. The wood component of the restoration was funded by the Nature Heritage Trust, Newcastle Ports Corporation, and the Hunter-Central Rivers Catchment Management Authority, and was installed by the NSW Land and Property Management Authority.

\section{LITERATURE CITED}

Albrecht, G. 2000. Rediscovering the Coquun: towards an environmental history of the Hunter River. Water Forum 2000. Our River: Our Future. Wyndham Estate, Branxton, NSW, Australia.

ANRA (Australian Natural Resources Atlas). June 2008a. Water resources - Overview - New South Wales: Surface water management area: Hunter River - Regulated. [online] URL: http://www.anra. gov.au/topics/water/overview/nsw/swma-hunter-riverregulated.html.

ANRA. June 2008b. Water resources - Overview New South Wales: Surface water management area: Hunter River - Unregulated. [online] URL: http:// www.anra.gov.au/topics/water/overview/nsw/swmahunter-river-unregulated.html.

Benda, L. E., N. L. Poff, C. Tague, M. A. Palmer, J. Pizzuto, S. Cooper, E. Stanley, and G. Moglen. 2002. How to avoid train wrecks when using science in environmental problem solving. Bioscience 52:1127-1136.
Bernhardt, E. S., M. A. Palmer, J. D. Allan, G. Alexander, K. Barnas, S. Brooks, J. Carr, S. Clayton, C. N. Dahm, J. Follstad-Shah, D. L. Galat, S. P. Gloss, P. Goodwin, D. Hart, B. Hassett, R. Jenkinson, S. L. Katz, G. M. Kondolf, P. S. Lake, R. Lave, J. L. Meyer, T. K. O'Donnell, L. Pagano, B. Powell, and E. Sudduth. 2005. Ecology: synthesizing U.S. river restoration efforts. Science 308:636-637.

Boulton, A. J. 2007. Hyporheic rehabilitation in rivers: restoring vertical connectivity. Freshwater Biology 52:632-650. DOI:10.1111/j.1365-2427.2006.01710.x.

Boulton, A. J., S. Findlay, P. Marmonier, E. H. Stanley, and H. M. Valett. 1998. The functional significance of the hyporheic zone in streams and rivers. Annual Reviews in Ecology and Systematics 29:59-81.

Boulton, A. J., S. J. Mika, D. S. Ryder, and B. Wolfenden. 2004. Raising the dead: can we restore the health of subsurface aquatic ecosystems by recovering geomorphic complexity using conventional river rehabilitation techniques? in G. Albrecht, editor. Airs, Waters, Places: Transdisciplinary Research in Ecosystem Health. University of Newcastle, Callaghan, NSW, Australia.

Boulton, A. J., H. Piégay, and M. D. Sanders. 2008. Turbulence and train wrecks: using knowledge strategies to enhance the application of integrative river science to effective river management. Pages 28-39 in G. J. Brierley and K. A. Fryirs, editors. River Futures: An Integrative Scientific Approach to River Repair. Island Press, Washington, D.C., USA.

Brierley, G., and K. Fryirs. 2009. Don't fight the site: three geomorphic considerations in catchmentscale river rehabilitation planning. Environmental Management 43:1201-1218. DOI:10.1007/ s00267-008-9266-4.

Brierley, G., K. Fryirs, A. Boulton, and C. Cullum. 2008. Working with change: the importance of evolutionary perspectives in framing the trajectory of river adjustment. Pages 65-84 in G. Brierley and K. Fryirs, editors. River Futures: An Integrative Scientific Approach to River Repair. Island Press, Washington, D.C., USA. 
Brooks, A. P., and G. J. Brierley. 2002. Mediated equilibrium: the influence of riparian vegetation and wood on the long-term evolution and behaviour of a near-pristine river. Earth Surface Processes and Landforms 27:343-367. DOI:10.1002/esp.332.

Brooks, A. P., and G. J. Brierley. 2004. Framing realistic river rehabilitation targets in light of altered sediment supply and transport relationships: lessons from East Gippsland, Australia. Geomorphology 58:107-123. DOI:10.1016/S0169-555X(03)00227-7.

Brooks, A. P., G. J. Brierley, and R. G. Millar. 2003. The long-term control of vegetation and woody debris on channel and flood-plain evolution: insights from a paired catchment study in southeastern Australia. Geomorphology 51:7-29.

Brooks, A. P., T. Howell, T. B. Abbe, and A. H. Arthington. 2006. Confronting hysteresis: wood based river rehabilitation in highly altered riverine landscapes of south-eastern Australia. Geomorphology 79:395-422. DOI:10.1016/j.geomorph.2006.06.035.

Bunn, S. E., and A. H. Arthington. 2002. Basic principles and ecological consequences of altered flow regimes for aquatic biodiversity. Environmental Management 30:492-507. DOI:10.1007/

s00267-002-2737-0.

Burkett, V. R., D. A. Wilcox, R. Stottlemyer, W. Barrow, D. Fagre, J. Baron, J. Price, J. L. Nielsen, C. D. Allen, D. L. Peterson, G. Ruggerone, and T. Doyle. 2005. Nonlinear dynamics in ecosystem response to climatic change: case studies and policy implications. Ecological Complexity 2:357-394. DOI:10.1016/j.ecocom.2005.04.010.

Chessman, B. C., J. E. Growns, and A. R. Kotlash. 1997. Objective derivation of macroinvertebrate family sensitivity grade numbers for the SIGNAL biotic index: application to the Hunter River system, New South Wales. Marine and Freshwater Research 48:159-172.

Clément, J.-C., R. M. Holmes, B. J. Peterson, and G. Pinay. 2003. Isotopic investigation of denitrification in a riparian ecosystem in western France. Journal of Applied Ecology 40:1035-1048.

Cundill, G. N. R., C. Fabricius, and N. Marti. 2005. Foghorns to the future: using knowledge and transdisciplinarity to navigate complex systems. Ecology and Society 10:8. [online] URL: http://ww w.ecologyandsociety.org/vol10/iss2/art8/.
Dahm, M. 2006. Snags, microhabitats, and macroinvertebrate assemblages in the lowland Hunter River, NSW. Master of Natural Resources thesis. University of New England, Armidale, Australia.

Dangar, H. 1828. Index and Directory to Map of the Country Bordering Upon the River Hunter. Joseph Cross, London, UK.

DLWC (NSW Department of Land and Water Conservation). 2000. Hunter, Karuah and Manning Catchments: State of the Rivers and Estuaries Report 2000. NSW Government, Sydney, Australia.

Dufour, S., and H. Piégay. 2009. From the myth of a lost paradise to targeted river restoration: forget natural references and focus on human benefits. River Research and Applications 25:568-581. DOI:10.1002/rra.1239.

Ehrenfeld, J. G. 2000. Defining the limits of restoration: the need for realistic goals. Restoration Ecology 8:2-9.

Erskine, W. D. 1985. Downstream geomorphic impacts of large dams: the case of Glenbawn Dam, NSW. Applied Geography 5:195-210.

Erskine, W. D. 1992. Channel response to largescale river training works: Hunter River, Australia. Regulated Rivers: Research and Management 7:261-278.

Erskine, W. D., and F. C. Bell. 1982. Rainfall, floods and river channel changes in the upper Hunter. Australian Geographical Studies 20:183-196.

Erskine, W. D., and R. F. Warner. 1988. Geomorphic effects of alternating flood- and drought-dominated regimes on NSW coastal rivers. in R. F. Warner, editor. Fluvial Geomorphology of Australia. Academic Press Australia, Sydney, Australia.

Erskine, W. D., and A.A. Webb. 2003. Desnagging to resnagging: new directions in river rehabilitation in southeastern Australia. River Research and Applications 19:233-249. DOI:10.1002/rra.750.

Fisher, S. G., J. B. Heffernan, R. A. Sponseller, and J. R. Welter. 2007. Functional ecomorphology: feedbacks between form and function in fluvial landscape ecosystems. Geomorphology 89:84-96. DOI:10.1016/j.geomorph.2006.07.013. 
Frothingham, K. M., B. L. Rhoads, and E. E. Herricks. 2002. A multiscale conceptual framework for integrated ecogeomorphological research to support stream naturalization in the agricultural Midwest. Environmental Management 29:16-33. DOI:10.1007/s00267-001-0038-7.

Fryirs, K. A., G. J. Brierley, N. J. Preston, and J. Spencer. 2007. Catchment-scale (dis)connectivity in sediment flux in the upper Hunter catchment, New South Wales, Australia. Geomorphology 84:297-316. DOI:10.1016/j.geomorph.2006.01.044.

Fryirs, K., A. Spink, and G. Brierley. 2009. PostEuropean settlement response gradients of river sensitivity and recovery across the upper Hunter catchment, Australia. Earth Surface Processes and Landforms 34:897-918. DOI:10.1002/esp.1771.

Gergis, J. L., and A. M. Fowler. 2009. A history of ENSO events since A.D. 1525: implications for future climate change. Climatic Change 92:343-387.

Harper, D., and M. Everard. 1998. Why should the habitat-level approach underpin holistic river survey and management? Aquatic Conservation: Marine and Freshwater Ecosystems 8:395-413.

Heemskerk, M., K. Wilson, and M. PavaoZuckerman. 2003. Conceptual models as tools for communication across disciplines. Conservation Ecology 7:8. [online] URL: http://www.consecol.org/ vol7/iss3/art8.

Hillman, M., and G. J. Brierley. 2005. A critical review of catchment-scale stream rehabilitation programmes. Progress in Physical Geography 29:50-70. DOI:10.1191/0309133305pp434ra.

Hillman, M., G. J. Brierley, and K. A. Fryirs. 2008. Social and biophysical connectivity of river systems. Pages 125-145 in G. J. Brierley and K. A. Fryirs, editors. River Futures: An Integrative Scientific Approach to River Repair. Island Press, Washington, D.C., USA.

Hobbs, R. J. 2007. Setting effective and realistic restoration goals: key directions for research. Restoration Ecology 15:354-357.

Howell, T. 2008. Fish responses to the introduction of structural woody habitat in two coastal rivers in New South Wales, Australia. PhD thesis. Griffith University, Nathan, Australia.
Hoyle, J., A. Brooks, G. Brierley, K. Fryirs, and J. Lander. 2008. Spatial variability in the timing, nature and extent of channel response to typical human disturbance along the Upper Hunter River, New South Wales, Australia. Earth Surface Processes and Landforms 33:868-889. DOI:10.1002/ esp.1580.

Hughes, F. M. R., A. Colston, and J. O. Mountford. 2005. Restoring riparian ecosystems: the challenge of accommodating variability and designing restoration trajectories. Ecology and Society 10:12. [online] URL: http://www.ecologya ndsociety.org/vol10/iss1/art12/.

Jansson, R., H. Backx, A. J. Boulton, M. Dixon, D. Dudgeon, F. M. R. Hughes, K. Nakamura, E. H. Stanley, and K. Tockner. 2005. Stating mechanisms and refining criteria for ecologically successful river restoration: a comment on Palmer et al. (2005). Journal of Applied Ecology 42:218-222.

Kasahara, T., T. Datry, M. Mutz, and A. J. Boulton (2009). Treating causes not symptoms: restoration of surface-groundwater interactions in rivers. Marine and Freshwater Research 60: 976-981. DOI: 10.1071/MF09047.

Keating, D., A. Spink, A. Brooks, M. Sanders, C. Miller, T. Schmidt, G. Kyle, K. Fryirs, and M. Leishman. 2008. The UHRRI Rehabilitation and Research Project 2002-2007. Macquarie University Press, Sydney, Australia.

King, E. G., and R. J. Hobbs. 2006. Identifying linkages among conceptual models of ecosystem degradation and restoration: towards an integrative framework. Restoration Ecology 4:369-378.

Kondolf, G. M., A. J. Boulton, S. O'Daniel, G. C. Poole, F. J. Rahel, E.H. Stanley, E. Wohl,A. Bång, J. Carlstrom, C. Cristoni, H. Huber, S. Koljonen, P. Louhi, and K. Nakamura. 2006. Process-based ecological river restoration: visualizing threedimensional connectivity and dynamic vectors to recover lost linkages. Ecology and Society 11:5. [online] URL: http://www.ecologyandsociety.org/voll1/ iss2/art5/.

Kyle, G., and M. R. Leishman. 2009a. Functional trait differences between extant exotic, native and extinct native plants in the Hunter River, NSW: a potential tool in riparian rehabilitation. River 
Research and Applications 25:892-903. DOI:10.1002/ rra.1192.

Kyle, G., and M. Leishman. 2009b. Plant functional trait variation in relation to riparian geomorphology: the importance of disturbance. Austral Ecology 34: 793-804. DOI:10.1111/ j.1442-9993.2009.01988.x.

Lake, P. S. 2000. Disturbance, patchiness, and diversity in streams. Journal of the North American Benthological Society 19:573-592.

Lake, P. S. 2005. Perturbation, restoration and seeking ecological sustainability in Australian flowing waters. Hydrobiologia 552:109-120. DOI:10.1007/s10750-005-1509-2.

Lake, P. S., N. Bond, and P. Reich. 2007. Linking ecological theory with stream restoration. Freshwater Biology 52:597-615. DOI:10.1111/ j.1365-2427.2006.01709.x.

Lansing, J. S. 2003. Complex adaptive systems. Annual Review of Anthropology 32:183-204.

Likens, G., K. F. Walker, P. E. Davies, J. Brookes, J. Olley, W. J. Young, M. C. Thoms, P. S. Lake, B. Gawne, J. Davis, A. H. Arthington, and R. L. Oliver. 2009. Ecosystem science: toward a new paradigm for managing Australia's inland aquatic ecosystems. Marine and Freshwater Research 60:271-279. DOI:10.1071/MF08188.

Mika, S. J., A. J. Boulton, D. S. Ryder, and D. Keating. 2008. Ecological function in rivers: insights from crossdisciplinary science. Pages 85-99 in G. J. Brierley and K. A. Fryirs, editors. River Futures: An Integrative Scientific Approach to River Repair. Island Press, Washington, D.C., USA.

Monteith, N. H. 1953. The contribution of historical factors to the present erosion condition of the Upper Hunter River. Journal of the Soil Conservation Service of NSW 9:85-91.

Moriarty, E. O., editor. 1870. Floods in the Hunter: Progress Report. Government Printer, Sydney, Australia.

Nelson, G. C., E. Bennett, A. A. Berhe, K. Cassman, R. DeFries, T. Dietz, A. Dobermann, A. Dobson, A. Janetos, M. Levy, D. Marco, N.
Nakicenovic, B. O’Neill, R. Norgaard, G. Petschel-Held, D. Ojima, P. Pingali, R. Watson, and M. Zurek. 2006. Anthropogenic drivers of ecosystem change: an overview. Ecology and Society 11:29. [online] URL: http://www.ecologya ndsociety.org/vol11/iss2/art29/.

Nilsson, C., R. Jansson, B. Malmqvist, and R. J. Naiman. 2007. Restoring riverine landscapes: the challenge of identifying priorities, reference states, and techniques. Ecology and Society 12:16. [online] URL: http://www.ecologyandsociety.org/vol12/iss1/ $\underline{\operatorname{art} 16 / .}$.

Palmer, M. A., E. S. Bernhardt, J. D. Allan, P. S. Lake, G. Alexander, S. Brooks, J. Carr, S. Clayton, C. N. Dahm, J. Follstad Shah, D. L. Galat, S. G. Loss, P. Goodwin, D. D. Hart, B. Hassett, R. Jenkinson, G. M. Kondolf, R. Lave, J. L. Meyer, T. K. O'Donnell, L. Pagano, and E. Sudduth. 2005. Standards for ecologically successful river restoration. Journal of Applied Ecology 42:208-217.

Parsons, M., C.A. McLoughlin, M. W. Rountree, and K. H. Rogers. 2006. The biotic and abiotic legacy of a large infrequent flood disturbance in the Sabie River, South Africa. River Research and Applications 22:187-201. DOI:10.1002/rra.905.

Peake, T. 2003. Hunter Bushland Resource Kit. Hunter Catchment Management Trust, Southward, Sydney, Australia.

Pedroli, B., G. de Blust, K. van Looy, and S. van Rooij. 2002. Setting targets in strategies for river restoration. Landscape Ecology 17 (Suppl. 1):5-18.

Pennington, D. D. 2008. Cross-disciplinary collaboration and learning. Ecology and Society 13:8. [online] URL: http://www.ecologyandsociety. org/vol13/iss2/art8/.

Pickett, S. T.A., W. R. Burch, Jr., and J.M. Grove. 1999. Interdisciplinary research: maintaining the constructive impulse in a culture of criticism. Ecosystems 2:302-307.

Poole, G. C., J. A. Stanford, S. W. Running, and C.A. Frissell. 2006. Multiscale geomorphic drivers of groundwater flow paths: subsurface hydrologic dynamics and hyporheic habitat diversity. Journal of the North American Benthological Society 25:288-303. 
Pusey, B. J., and A. H. Arthington. 2003. Importance of the riparian zone to the conservation and management of freshwater fish: a review. Marine and Freshwater Research 54:1-16. DOI:10.1071/MF02041.

Pusey, B. J., M. J. Kennard, and A. H. Arthington. 2004. Freshwater Fishes of Northeastern Australia. CSIRO Publishing, Melbourne, Australia.

Raine, A. 2000. State of the Hunter River. Water Forum 2000. Our River: Our Future. Wyndham Estate, Branxton, NSW, Australia.

Ryder, D. S., and W. Miller. 2005. Setting goals and measuring success: linking patterns and processes in stream restoration. Hydrobiologia 552:147-158. DOI:10.1007/s10750-005-1512-7.

Ryder, D. S., G. Brierley, R. Hobbs, G. Kyle, and M. Leishman. 2008a. Vision generation: what do we seek to achieve in river rehabilitation? Pages 16-27 in G. J. Brierley and K. A. Fryirs, editors. River Futures: An Integrative Scientific Approach to River Repair. Island Press, Washington, D.C., USA.

Ryder, D., S. Mika, P. Frazier, R. Rolls, and A. Burns. 2008b. Environmental flows in NSW North Coast: review of scientific principles and current knowledge. Report to the NSW Department of Environment and Climate Change. University of New England, Armidale, Australia.

Scealy, J. A., S. J. Mika, and A. J. Boulton. 2007. Aquatic macroinvertebrate communities on wood in an Australian lowland river: experimental assessment of the interactions of habitat, substrate complexity and retained organic matter. Marine and Freshwater Research 58:153-165. DOI:10.1071/ MF06105.

Schneider, G. 2007. Where land meets water resource kit: a guide to riparian management in the Hunter Valley. Hunter-Central Rivers Catchment Management Authority, Tocal, NSW, Australia.

Sime, P. 2005. St. Lucie Estuary and Indian River Lagoon conceptual ecological model. Wetlands 25:898-907.

Spencer, J., K. Fryirs, D. Keating, and G. Brierley. 2004. River Styles in the Upper Hunter Catchment. Macquarie University, Sydney, Australia.
Spink, A., K. Fryirs, and G. Brierley. 2009. The relationship between geomorphic river adjustment and management actions over the last 50 years in the Upper Hunter catchment, NSW, Australia. River Research and Applications 25:904-928. DOI:10.1002/ rra.1197.

van Niekerk, A. W., G. L. Heritage, L. W. Broadhurst, and B. P. Moon. 1999. Bedrock anastomosing channel systems: morphology and dynamics of the Sabie River, Mpumulanga Province, South Africa. Pages 33-51 in A. J. Miller and A. Gupta, editors. Varieties of Fluvial Form. John Wiley and Sons, Chichester, UK.

Ward, J. V., F. Malard, and K. Tockner. 2002. Landscape ecology: a framework for integrating pattern and process in river corridors. Landscape Ecology 17 (Suppl. 1):35-45.

Ward, J. V., K. Tockner, U. Uehlinger, and F. Malard. 2001. Understanding natural patterns and processes in river corridors as the basis for effective river restoration. Regulated Rivers: Research and Management 17:311-323. DOI:10.1002/rrr.646.

Wiens, J. A. 2002. Riverine landscapes: taking landscape ecology into the water. Freshwater Biology 47:501-515.

Wohl, E. 2005. Compromised rivers: understanding historical human impacts on rivers in the context of restoration. Ecology and Society 10:2. [online] URL: http://www.ecologyandsociety.org/vol10/iss2/ $\underline{\operatorname{art} 2 / .}$.

Wohl, E., P. L. Angermeier, B. Bledsoe, G. M. Kondolf, L. MacDonnell, D. M. Merritt, M. A. Palmer, N. L. Poff, and D. Tarboton. 2005. River restoration. Water Resources Research 41:W10301. DOI:10.1029/2005WR003985.

Wolfenden, B., S. Mika, A. Boulton, and D. Ryder. 2005. Assessing change in riverine organic matter dynamics in the Hunter River, NSW, over the last 200 years: implications for stream restoration. Pages 697-703 in Fourth Australian Stream Management Conference, Launceston, Tasmania, Australia.

Wolfenden, B. J. 2009. Leaf litter dynamics and the rehabilitation of degraded coastal rivers in NSW, Australia. PhD thesis. University of New England, Armidale, Australia. 
Wood, P. J., and P. D. Armitage. 1997. Biological effects of fine sediment in the lotic environment. Environmental Management 21:203-217.

Wood, W. A. 1972. Dawn in the Valley: The Story of Settlement in the Hunter Valley to 1833. Wentworth Books, Sydney, Australia. 